\title{
Argümantasyonun Öğrencilerin Bilimi Sözde-Bilimden Ayırma Becerilerinin Geliştirilmesi Üzerine Etkisi
}

\section{An Effectiveness of Engaging in Argumentation on Students' Ability to Demarcate Science from Pseudoscience}

\section{Merve ARIK ${ }^{*}$}

\author{
Behiye AKÇAY**
}

Öz. Bu araştırmada ortaokul yedinci sınıf öğrencilerinin bilim sözde-bilim ayrımı yeteneklerinin Argümantasyon Tabanlı Öğrenme (ATÖ) etkinlikleri yoluyla geliştirilmesi hedeflenmiştir. Bu amaçla hazırlanan etkinlikler kozmik bilim, refleksoloji, astroloji, numeroloji ve biyoenerji sözde-bilimsel alanlara ait örnek vakalar üzerine kurgulanmıştır. Araştırmaya 2014-2015 eğitim-öğretim yılı ikinci döneminde, İstanbul ili Esenyurt ilçesinde bulunan bir ortaokulda öğrenim gören ve Bilim Uygulamaları dersini alan 24 yedinci sınıf öğrencisi beş hafta süresince katılmışır. Araştırma öncesi gerçekleştirilen yarı yapılandııılmış görüşmeler ile öğrencilerin var olan bilim sözde-bilim ayrımı ölçütleri, süreç sonunda gerçekleştirilen son görüşmelerde geliştirdikleri ölçütlerle karşılaştırılarak incelenmiştir. Araştırma sonucunda argümantasyon ile öğrencilerin bilim sözde-bilim ayrımına yönelik bilgilerinin ve tartışma becerilerinin arttı̆̆ı gözlenmiştir. Öğrenciler son görüşmelerde ön görüşmelere göre daha fazla ölçüt geliştirmiş ve daha kapsamlı sorgulama yapmıştır. Bu araștırmanın ATÖ yaklaşımını bilim sözde-bilim ayrımı tartışması bağlamında kullanan ilk araştırma olması bakımından Fen Bilimleri öğretmenlerine kılavuzluk edebileceği ve gelecekteki araştırmacılara yol göstereceği düşünülmektedir.

Anahtar Kelimeler: Argümantasyon, Bilim, Sözde-Bilim.

\begin{abstract}
In this research, it was aimed to develop seventh grade studens' demarcation skills using Argument Based Learning (ABL) activities. These activities were cosmic science, reflexology, astrology, numerology and bioenergy from pseudo-scientific fields. During the spring semester of 2014-2015 academic year, twenty-four seventh-grade students from a state middleschool in Esenyurt, Istanbul participate the study. The study took place in Science Applications course for five weeks. semi-constructed interviews done before and after the study to find out students' science pseudo-science separation criteria as a result of the research, it has been observed that with the argumentation, knowledge and discussion skills of the students on science pseudo-science are increasing. Students have developed more scientific criteria and made more extensive inquiries in the final negotiations than previous interviews. It is concluded that this research will guide the science teachers and lead the future researchers to be the first to use the $A B L$ approach in the context of science pseudo-science discrimination.
\end{abstract}

Keywords: Argumentation, Science, Pseudo-Science.

\section{Toplumsal Mesaj.}

Bilime olan ilginin artışıla birlikte, bilim insanları tarafından sözde-bilimsel olarak adlandirılan "mucize ilaç", "yeni harika tedavi", "uzaylı ziyaretçilerin varlığının kanıtı", "yeniçă̆ ruhani enerjisi" gibi konuların anlatılı̆̆ı kitapların toplum tarafından ilgi gördüğü bilinmektedir. Bu nedenle bireylere sözde-bilimsel iddiaların bilimsel bilgiden nasıl ayırt edilebilecekleri konusunda yardımcı olunmalıdır.

Public Interest Statement. As a result of increase in science, different subjects become popular in society like as as "miracle medicine", "new wonderful treatment", "proof of the existence of the alien", "new age spiritual energy" which were called pseudo-scientific knowledge by scientists. For this reason, individuals should be helped to teach how to distinguish pseudo-scientific claims from scientific knowledge.

\footnotetext{
* Milli Eğitim Bakanlığı, mervearik@hotmail.com

${ }^{* *}$ Prof. Dr., İstanbul Üniversitesi, Hasan Ali Yücel Eğitim Fakültesi Matematik ve Fen Bilimleri Eğitimi Bölümü, bakcay@istanbul.edu.tr
} 


\section{GiRiş}

Fen okur-yazarlı̆̆ı çağdaş fen müfredatlarının vazgeçilmez amacıdır (The American Association for the Advancement of Science [AAAS], 1993). Benzer şekilde Türkiye'de de 3, 4, 5, 6, 7 ve 8. sınıflar için hazırlanan IIlköğretim Fen Bilimleri Dersi Öğretim Programı'nın vizyonu; "tüm öğrencileri fen okur-yazarı bireyler olarak yetiştirmek" olarak tanımlanmıştır (Milli Eğitim Bakanlığı [MEB], 2013). Fen ve teknoloji okur-yazarlığı tanımları incelendiğinde eğitimcilerin fen okur-yazarlığı için genellikle bilimsel bilginin doğasını kavramak, bilimsel bilgi ile bilimsel olmayan bilgiyi ayırmak, bilimsel olguları öngörmek, karşılaşılan problemlere yönelik bilimsel süreç becerilerini kullanmak gibi başlıklara tanımlarında yer verdikleri görülmektedir (National Science Education Standards [NSES], 1996). Bu doğrultuda bireylerin eğitimi, yalnızca bilimsel gerçeklerin, kanunların, teorilerin aktarımı olarak görülmemekte, bilimsel bilginin değerinin, gücünün, geçerliliğinin ve sınırlılıklarının da değerlendirilebilmesi beklenmektedir (Turgut, Akçay ve İrez, 2010).

\subsection{Bilim ve Sözde Bilim Ayrımı}

Bilimsel bilginin, bilimsel olmayan bilgiden ve sahte bilimsel bilgiden veya bilimi taklit eden bilgiden ayrıması sorununa "ayrım problemi" (demarcation problem) denilmektedir (Tutar, 2014). Ayrım problemi "bilimin sınırlarını belirleme (demarcation problem)" sorunsalı üzerine oluşmuştur. Bilimin sınırlarını belirleme, öncelikle bilimi ve bilimselliği tanımlama ile ilgili olsa da sorun bununla sınırlı değildir. Bilimsel bilginin epistemolojik yapısını ve değerini, bilimsel bilgiyi bilimsel olmayan bilgiden ayıran özellikleri, bilimsel olmayan bilginin özelliklerini de aynı şekilde tanımlamak gerekir.

Bilimin sınırlarını belirleme sorunu sadece felsefi kulislerde çözüm bekleyen alansal bir tartışma olmanın ötesinde gündelik hayatı da ilgilendiren başka bir boyut daha içermektedir. Öyle ki; gün geçtikçe insanların bilime olan ilgisi artmakta ve bilim günlük hayatımızı etkileyen faktörlerin başında gelmektedir. Bir fikir, araştırma ya da alana "bilimsel" değer biçilmesi insanların doğrudan ona dikkat kesilmesine ve değer vermesine yol açmaktadır. Bilimin bu kadar değer görmesi bilim adı altında sözde-bilimsel alanların doğuşuna sebep olmuştur. Dolayısıyla bilimin sınırları sorununun, bilimi sözde-bilimden nasıl ayırırız sorusu altında tartışıması söz konusu olmuştur.

Sözde-Bilim (Sahte-Bilim)'in tanımı ve kriterleri üzerinde düşünürler arasında ortak bir kanaat yoksa da sözde bilim genellikle "bilimsel olmadığı halde taraftarlarınca bilimsel olduğu izlenimi verilen öğreti veya aktiviteler" olarak tanımlanmaktadır (Hansson, 2008). Sözde-bilim bilimsel argümanları kullanır; ancak bilimsel çalışmaların gerektirdiği materyal, metot ve standartları taşımaz (Tutar, 2014).

Sözde-bilimin özellikle 17. yüzyılda bilimin popülerliği ile bilime verilen değerin artışına paralel olarak geliştiği söylenebilir. Bu dönemde bilimsel devrimlerin cazibesine kapılanların ortaya koyduğu metafiziksel söylemler, retorik, sözde-bilimsel iddialar ile bilimin iddia ve söylemleri birbirine karışmış; bilimsel olan ve olmayan konusuna özen göstermeden alelade bir araştırmaya, fikre acelece "bilimsellik" atfedilmiştir (Tutar, 2014).

Felsefenin birçok alanında olduğu gibi "bilimin sınırlarını belirleme sorunu” da oldukça karmaşık bir süreç geçirmiş ve geçirmeye devam etmektedir. Ayrım probleminin çözümü mantıksal pozitivizm, yanlışlanabilirlik (falsifiability) ölçütü, bilimsel devrimler, ilerlemeci programlar ve epistemolojik anarşizm gibi felsefi tartışmalarla ortaya atılmışır.

Mantıksal pozitivizm olarak anılan düşünce biçimine göre bilimin yöntemi tümevarımdır ve buradan hareketle bilimi, bilim olmayandan ayırt etmek için ölçüt olarak "doğrulanabilirlik ilkesi" (verifiability) kullanılır (Chalmers, 2013). Bir önerme, gözlem ve deneyle elde edilen verilerle uyumluluk içindeyse yani yapılan gözlemin ve deneyin sonuçları var olan olguları destekliyorsa, diğer bir değişle olgular "doğrulanabiliyorsa", o önermeler bilimsel olarak kabul edilmeliydi. Doğrulanabilirlik ilkesine göre bir ifade ampirik kanıtlarla doğrulanamıyor ve hangi koşullar altında doğrulanabileceği söylenemiyorsa o düşünce ya da ifade bilimsel değildir (Chalmers, 2013; Sönmez, 2008; Uslu, 2011). 
Doğrulama ilkesinin dayanağını oluşturan gözlem ve tümevarımın bilimselliğin kriteri olduğu iddiasının bir açıklamayı bilimsel kılmak için yeterli olmayacağını ilk ifade eden kişi Karl Popper olmuştur. Popper, mantıksal pozitivistlerin öne sürdüğü ölçütlerin bir açmaza dönüştügünü savunmuş ve ayrım probleminin çözümü için "yanlışlanabilirlik" ölçütünü önermiştir (Popper, 1934). Yanlışlamacı kurama göre bir kuramı doğrulayamayız, kanıtlayamayız, temellendiremeyiz; fakat sınayabiliriz, çürütebiliriz ve yanlışlayabiliriz. Bu doğrultuda bilimsel önermeler, doğrulanabilir, belgelenebilir ve temellendirilebilir önermeler değil; aksine sınanabilir, yanlışlanabilir ve çürütülebilir önermelerdir (Sönmez, 2008).

Kuhn, Popper'ın yanlışlamaya ve çürütmeye ilişkin görüşlerini yetersiz bulur. Ona göre bilimsel kuramlar yanlışlamaya karşı oldukça dayanıklıdırlar, bu yüzden aykırılıklar ve karşıt örneklerden söz etmek daha doğru olur (Sönmez, 2008). Böylece ayrım probleminin çözümüne, eserinde bilimsel topluluk üyelerinin paylaştıkları veriler olarak tanımladığı "paradigma" kavramı ile katılmış, ortaya çıkan problemlerin çözümüne katkıda bulunan paradigmalara bilimsel olarak değer verilebileceğini ifade etmiştir. Paradigmaların değişime belli bir süre direnç gösterebileceğini ve bu sırada bilim camiasında anomaliler meydana geleceğini iddia etmiş, yapılacak araştırmalar yoluyla yeni bir paradigmanın kabulü ile bu sürecin sonuçlanacağını öngörmüştür (Kuhn, 1962). Kuhn, bu değişim için "bilimsel devrim" tanımını kullanmıştır. Eski paradigma terk edilip, yerini yeni paradigma almıştır. O halde; Kuhn'a göre astroloji örneği sadece yanlışlanabilirliği söz konusu olmadığından değil, daha çok bir problem çözme girişimi olmadığından sözde-bilimsel olarak nitelendirilir (Nickles, 2006).

Ayrım problemine, bilimsel araştırma programları önermesi ile katılan Imre Lakatos (1981), bilimsel önermelerin, Popper'ın ifade ettiği önermeler kadar basit bir yapıya sahip olmadığını iddia etmiştir. Bilim ile sahte-bilim ayrımının Popper'ın ileri sürdüğü gibi tek tek hipotezler ve teoriler incelenerek yapılamayacağını savunur. Kuhn'u ise açık hiçbir ölçüt sunmamakla eleştirmiş̧ir (Turgut, 2009). Ona göre bilim, ne basit bir deneme-yanılma yöntemidir ne bir varsayımlar ve çürütmeler dizisidir ne de salt bir boz-yap çözme sürecidir. Lakatos'a göre bilim bir "araştırma programı" içermeli veya bir araştırma programına dayanmalıdır. Lakatos'un dejenere programlar dediği sahte-bilimlerde ise, baştan kabul edilmiş iddialar bilinen gerçeklerle uyumlu kılınabilmek için yapay olarak teoriler üretilir. Sonuç olarak Lakatos'a göre bilimi, sahte-bilimden ayıran şey, bilimin bir "araştırma programı" içermesi veya bir araştırma programına dayanmasıdır. Bir araştırma programının olmazsa olmaz özellikleri, yepyeni ön deyiler üretebilme yeteneği ve kendini değiştirmeye, geliştirmeye açık olmasıdır (Uslu, 2011).

Bu ölçüt geliştirme tartışmalarına ters olarak; Feyerabend evrensel ölçütlere karşı çıkmıştır. Feyerabend, bilimi bilim olmayandan ayırt eden bir yöntemin olmadığını iddia ederek, bilimsel bilginin diğer geleneksel bilgi türlerinden üstün olduğu iddiasının batı modernizminin emperyalist söyleminden kaynaklandığını ileri sürer (Uslu, 2011). Feyerabend'e göre bilimsel bilgi, diğer bilgi türleri gibi herhangi bir bilgidir ve onlardan üstün değildir. Feyerabend kendisinden önceki bilim felsefecilerinin öngördükleri tüm ölçütleri reddederek geliştirdiği yöntemi "anarşist bilgi kuramı" olarak adlandırmıştır (Feyerabend, 1989). Bu kuram bilimde ölçütlerden sıyrılarak özgürleşmenin gerekliliğini savunur. Bilimsel faaliyet zannedildiği gibi, herhangi bir bilimsel ölçüte veya yönteme dayanmaz. Bilimde her şey mümkündür. Bilim için öngörülen yöntemler, ölçütler ve kurallar, bilimde yeniliklerin ve bilim adamının yaratıcılı̆ının önündeki engellerdir (Sönmez, 2008).

Feyerabend'in ölçüt belirleme çabalarının gereksiz olduğunu savunmasına karşın, bu yöndeki çalışmalar ve tartışmalar günümüze kadar sürmüş ve halen devam etmektedir (Gillies, 1998; Nickles, 2006). 20. Yüzyılda ölçüt belirleme yönünde yapılan araştırmaların tümü Mantıksal pozitivizimi (Viyana Çevresi) savunan Schlick, Carnap, Reichenbach, Neutrah ve Wittgenstein'in yanı sıraPopper, Kuhn, Lakatos gibi felsefecilerin tek yöntem, tek ölçüt geliştirme gayretine karşın ayrım sorununu birden çok ölçütle çözmeye odaklanmıştır. Bu durumun sebebi bahsi geçen filozofların öne sürdüğü tekil ölçütlerin sorunu çözmede yetersiz kalmasıdır. 
20. yy ölçüt belirleme çalışmalarında Smith ve Scharmann'nın (1999) yaklaşımı büyük önem taşımaktadır. Çünkü bu yaklaşım, bilimsel bilgiyi diğer disiplinlerden kesin çizgilerle ayıracak ölçüt arayışı yerine, bir disiplini daha az veya daha fazla bilimsel yapan öğelere odaklanılmasını önermiştir. Otorite, nesnellik ve sınanabilirlik gibi kavramları tartışan araştırmacılar fen eğitimi ve bilim felsefesi literatürünü gözden geçirerek bir alanı daha çok bilimsel yapan özellikleri "amaçlar ve süreç" ve "bilimin değerleri" başlıkları altında ele almıştır (Turgut, 2009).

20. yy'da ayrım sürecine katkıda bulunan bir diğer önemli isim Thagard olmuştur. Thagard mantıkçı pozitivistlerin, Popper ve Lakatos'un bilimselliği sadece "mantık" boyutu ile Kuhn'un ise "tarihsel süreç" boyutu ile değerlendirmesine karşı çıkmıştır. Ona göre bir görüşün bilimselliğini değerlendirirken hem mantıksal hem de tarihsel boyutunu bir arada ele almak gerekmektedir. Ayrıca bunların yanı sıra teoriyi savunan bilimsel topluluğu da ele almak gerekmektedir. Thagard (1978), bu çerçevede bir teorinin bilimselliğini, "mantık", "tarih" ve "epistemik inançlar" boyutları altında değerlendirmiştir. Bilimin sınırları ile ilgili bir başka çoklu ölçüt önerisi İngiliz filozof P. Kitcher'dan gelmiştir. Ona göre, bir teorinin bilimselliğini belirlemede üç temel özellik aranmalıdır. Birincisi, bir teorinin doğruluğunun sınanmasında kullanılan yardımcı hipotezler de ilgili teoriden bağımsız olarak ayrıca sınanabilir olmalıdır. ikincisi, bilimsel pratikler birbiriyle ilişkili bütünlerdir; yalıtılmış veya fırsatçı metotların yamalı bohçaları değillerdir. Onlar, problem çözme ile ilgili az sayıda stratejiyi çok çeşitli durum ve problemlere uygularlar. Bilimsellik iddiasındaki bir teori, problem çözme konusunda diğer bilimlerin kullandığı temel stratejileri kullanıyor olmalıdır. Üçüncüsü, iyi bilimsel teoriler, önümüze yeni bilimsel araştırma alanları açmaları anlamında "doğurgandırlar". Dolayısıyla bilimsellik iddiasındaki bir teorinin bu özelliğe sahip olması beklenir (Mahner, 2007).

Alman felsefeci Gerhard Vollmer bir teori veya görüşün bilimselliğinin iç ve dış tutarlıık kriterlerine göre belirlenmesini önerir. "iç tutarlıık" ile o, teorinin kendi içinde çelişkiler ve döngüsellikler içermemesini; "dış tutarlıık" ile teorinin, bilimin güvenilir bilgilerinden oluşan mevcut kütlesi ile uyum içinde olmasını anlar. Bunların yanında Vollmer'a göre bilimsel teoride; açıklama gücüne sahip olma, öndeyiler içerme, değişebilir olma, doğurgan olma, yeni bilimsel araştırma alanları açabilme ve basit olma özellikleri bulunmalıdır (Mahner, 2007).

Merton ise bilimin ölçütü yerine kullanılabilecek dört etik ilkeden söz etmiştir. Bunlar; iddiaların nesnel ölçütlere göre değerlendirilmesi gerektiğini belirten evrensellik, bilimsel buluşların toplumun tümüne ait olduğu yönünde anlam taşıyan toplumsallık, bilim adamlarının sahip olabilecekleri kişisel veya ideolojik eğilimlerin etkilerini törpüleyecek kurumsal bir kontrol mekanizmasının oluşturulmasını gerektiren ilgisizlik ve son olarak bilim alanına giren her türlü inancın içtenlikle bağlanılmış olunsa bile ayrıntııı bir sorgulamasının oluşturulmasını gerektiren örgütlü şüphecilik'den oluşmaktadır (Hansson, 2008).

Wynn ve Wiggins (2008), "Yanlış Yönde Kuantum Sıçramalar" adlı eserinde bilim ve sözde-bilim arasındaki farkları yöntemsel açıdan değerlendirmiştir:

- Bilimsel ve sözde-bilimsel gözlemler: Bilimsel gözlemler veya açıklamalar gerçek olayların gözlemlerine dayalı iken; sözde-bilimsel gözlemler gerçeklikten yoksundur. Gözlemcinin önyargıları gözlemin konusunu oluşturur ve inançlardan bağımsız değildir.

- Bilimsel hipotezler ve sözde-bilimsel hipotezler: Gerçek bilimsel hipotezler daha kesin ve basit denklemlerle ifade edilir. Hata oranı azdır ve gözlemci tarafından önyargılardan ve yanlı değerlendirmelerden arındııılmıştır. Sözde-bilimsel hipotezler ise, bilimsel hipotezlerle uyum içinde olmamakla birlikte, duygulara başvurur ve bunları sınamak çoğu zaman mümkün değildir.

- Bilimsel ve sözde-bilimsel öngörüler: Bilimsel öngörüler hipotezlerle uyumludur. Hipotezden öngörüye gitmek için bilim insanları tümdengelimsel yaklaşımı kullanırlar. Sözde-bilimsel öngörüler hipotezi izlemezler, çok genel ve belirsizdirler. 
- Bilimsel ve sözde-bilimsel deney: Bilimsel deneylerde ölçümler nesnel, tekrarlanabilir ve hata oranı düşüktür. Sözde-bilimlerde ise ölçümler öznel, kişiye bağımlı, tekrarı zor ve hilelidir.

- Yeniden çevrim: Bilimde sınılı sayıdaki deneyler ile genel bir hipotez kanıtlanamaz; sadece desteklenir. Sözde-bilimciler ise sınırlı sayıdaki deneyle hipotezlerinin kanıtlandığı rahatlığıyla hareket eder.

Yapılan araştırmalar sonucunda, bilim insanlarının ve düşünürlerin üzerinde anlaştığı genel geçer bir bilimsel ölçütün varlığından söz edilemeyeceği gibi ölçüt arama çalışmalarının son bulması da mümkün görünmemektedir. Bunun yanında, bu sorgulama girişimleri ve çözümsüz gibi görünen felsefi tartışmalar bir süreç olarak uygun bir biçimde planlanabilirlerse, sonunda kesin bir cevaplar dizisine ulaşmak mümkün olmasa bile son derece etkili olabileceği düşünülmektedir (Turgut, Akçay ve İrez, 2010). Günümüzde fen ve teknoloji alanındaki gelişmeler fen eğitiminin öneminin gün geçtikçe artmasına ve bu alanda gelişmelere neden olmuştur. Fen eğitiminde kullanılan öğrenmeöğretme yaklaşımları bu bağlamda önem arz etmektedir. Bu öğretme-öğrenme yaklaşımlarından biride argümantasyondur.

\subsection{Fen Eğitiminde Argümantasyon}

Son yıllarda fen eğitimi alanında yapılan çalışmalar öğrenciyi ezbere yönelten geleneksel etkinlikler yerine öğrencinin düşünmesini ve öğrenme sürecine aktif katılımını sağlayan yaklaşımları ön plana çıkarmaktadır (Üstünkaya ve Savran-Gencer, 2012). Bu alternatif yaklaşımlardan biri de Argümantasyon Tabanlı Öğrenme Yaklaşımıdır Bu yaklaşım öğrencilerin öğrenme sürecine katıımlarını artırmakta ve bu sebeple daha etkin bir öğrenme ortamı oluşturulabilmektedir (Günel, Kıngır ve Geban, 2012). Son yıllarda birçok çalışma da öğrencilerin bilimsel düşünmeyi anlayabilmesi için bilimi argümantasyon olarak yaşamaları gerektiğini vurgulamıştır (Driver, Newton ve Osborne, 2000; Duschl ve Osborne, 2002; Erduran ve Jimenez-Aleixandre, 2007; Kuhn, 1993).

Sandoval ve Millwood (2008), bilimsel argümantasyonu anlayan öğrencilerin, bilimin doğasını anlayabileceklerini, feni uygulamayan insanların bilimsel argümantasyona gerçekten katılamayacaklarını iddia ederek, argümantasyon ve bilimin doğası arasında güçlü bir ilişki olduğunu belirtmişlerdir. Benzer şekilde, Osborne, Erduran ve Simon (2004) argümantasyona dayalı öğretim boyunca, öğrencilerin iddialarını desteklemek için delil kullandıklarını, diğer bireylerin iddialarını değerlendirerek bilim adamlarının tartışmacı uygulamalarını özümsediklerini böylece argümantasyonun öğrencilerin bilimin doğası ve bilgiyle ilgili uygulamalarını geliştirmelerine yardımcı olabilen bir konuşma yolu olduğunu vurgulamışlardır. Bilimsel tartışma, bilimin yapısının anlaşılması ve bilginin yapılandırılmasında önemli bir yere sahiptir. Tartışma ile öğrencilerin bilim adamları gibi düşünmeleri desteklenir, daha eleştirel düşünmeleri sağlanır ve öğrenciler daha sağlam ve fonksiyonel bilgi yapılandırabilirler (Uluçınar-Sağır ve Kılıç, 2013). Cavagnetto'e (2011) göre, argüman yapılandırma süreci eleştirel muhakeme, bilişsel beceriler ile kişisel anlayışı yansıtmanın yanı sıra öğrencilerin kendi düşünceleri hakkında düşünmelerine de olanak sağlar. Ayrıca bilimsel tartışma; kanıt değerlendirme, alternatifleri inceleme, bilimsel iddiaların geçerliliğini ve karşı kanıtları değerlendirmeyi de içerir (Driver vd., 2000). Bu gerekçelerle araştırmada öğrencilerde bilim-sözde bilim farkındalığını geliştirmek için argümantasyon tabanlı öğrenme etkinliklerine yer verilmesi uygun görülmüştür.

Bu araştırma, bilim sözde-bilim ayrımı tartışmasını ortaokul düzeyine taşıması ve bilim sözde-bilim ayrımı öğretiminde Argümantasyon Tabanlı Öğrenme etkinliklerine yer veren ilk araştırma olması bakımından fen bilimleri öğretmenlerine kılavuzluk edebileceği ve gelecekteki araştırmacılara yol göstereceği düşünülmektedir. Ayrıca Seçmeli Bilim Uygulamaları dersinin esnek ders programı çerçevesinde, süreçte gerçekleştirilen etkinlik ve oluşturulan kazanımların bu dersin alternatif kapsamı ve işlenişi ile ilgili fen bilimleri öğretmenlerine ışık tutacağı öngörülmektedir. 


\subsection{Problem}

Bilime olan ilginin artışıla birlikte yeni teoriler daha çok gündeme gelmekte ve bilim insanları önemsemese de toplumda ciddi ilgi bulabilmektedir (Gardner, 1957). Bu teoriler hemen hemen her gün televizyon, dergi, film, gazete gibi kitle iletişim araçlarıyla sunulmakta ve "mucize ilaç", "yeni harika tedavi", "uzaylı ziyaretçilerin varlığının kanıtı", "yeniçağ ruhani enerjisi", "içindeki devi uyandır", "kendini ateşle" gibi çarpıcı nitelendirmelerle geniş kitleleri kolayca peşinden sürükleyebilmektedir. Hatta bilim insanları tarafından "sözde-bilimsel (pseudoscientific)" olarak adlandırılan bu tür teorilerin anlatıldığı kitaplar, kabul görmüş bilimsel yayınlardan daha çok satmaktadır (Park, 2000). Neyin bilim olup neyin bilim olmadığı konusunda yaşanan karmaşa da dolayısıyla giderek artmaktadır. Bu nedenle bilimin nasıl bir süreç olduğunun bireylerle mutlaka paylaşılması ve sözde-bilimsel iddiaların nasıl farkına varılabileceğinin ele alınması önemlidir. Toplumda bu farkındalığın gelişebilmesinin yolunun her alanda olduğu gibi eğitimden geçtiği bilindiğinden; öncelikle fen eğitiminde bu sorunsala yönelik çalışmaların gerçekleştirilmesi gerekmektedir.

Öğrencilerde bu farkındalığın geliştirilebilmesi için öncelikle öğrencilerin bilgileri, verileri ve intimalleri sorgulayıcı ve eleştirel bir düşünce tarzıyla değerlendirerek sağıklı kararlar verebilmesinin yolunun açılması gerekmektedir. Öğrenciler kişisel ve toplumsal meselelerde karar verirken açık fikirli, kuşkucu ve sorgulayıcı bir tutumla alternatif açıklamalar üzerinde düşünebilmeli; tartışmalarda öne sürülen iddiaları, gerekçeleri ve argümanları eleştirel olarak değerlendirerek bilinçli kararlar geliştirebilmelidir (Tümay ve Köseoğlu, 2011).

\subsection{Bilim Sözde-Bilim Ayrımına Yönelik Çalışmalar}

Türkiye'de ve dünyadaki eğitsel çalışmalar incelendiğinde bilim sözde-bilim ayrımına yönelik eğitsel çalışmalara fazlaca rastlanamamaktadır. Felsefi tartışmalar ve ölçüt belirleme sorunsalı üzerinde oldukça yoğun bir literatüre sahip olan bu alanda öğrenciler ve öğretmenler tarafından nasıl algılandığı, öğretmen ve öğrencilerin ayrıma yönelik algılarını ve tartışma becerilerini geliştirmeye yönelik çalışmalara büyük ölçüde yer verilmediği görülmüştür. Bu yöndeki mevcut çalışmalara aşağıda yer verilmiştir.

Turgut, Akçay ve İrez (2010) araştırmasında; fen bilgisi öğretmen adaylarıyla bilim sözde-bilim ayrımını geliştirmeye yönelik bir dönem boyunca çalışmalar yürütmüş ve sonuçlar nitel olarak incelenmiştir. Çalışmalar astroloji örnek olayı üzerine yapılandırılmış, araştırma sonuçları bir girişim olarak bilim, deney, gözlem, teoriler, yasalar, modeller, bilimsel yöntem ve sosyo-kültürel değerlerin bilimdeki rolü gibi alt boyutlarda adayların inanışlarını geliştirebildiklerini göstermiştir.

Turgut (2009) çalışmasında, öğretmen adaylarının bilimsel, sözde-bilimsel ayrımına yönelik algıları, yeterlikleri inceleme konusu yapıımıştır. 57 birinci sınıf öğretmen adayı ile yürütülen araştırmanın veri kaynaklarını açık uçlu sorular, bir örnek olay metni ve rastgele seçilmiş on bir aday ile yapılan görüşmelerin kayıtları oluşturmuştur. Araştırma sonuçları adayların büyük çoğunluğunun eleştirel bir tavır içinde olmadığını, bir uçta ispatlanabilirlik üzerine kurulu, diğer uçta ise her şeyin inceleme konusu yapıldığı bir bilim anlayışı sergilediklerini ve bilimsel, sözde-bilimsel ayrımında büyük oranda yetersiz kaldıklarını göstermiştir.

Çetinkaya, Turgut, Duru ve Ercan'nın (2015) sekizinci sınıf öğrencileri ile gerçekleştirdiği çalışmada öğrencilerin bilim sözde-bilim bağlamındaki etkinlikler yoluyla ilgili sözde-bilim alanlarına yönelik akademik becerilerinin geliştirilmesi amaçlanmıştır. Öğrencilerin ilgili sözde-bilim alanlarına dair bilimsel bilgi düzeylerinin gelişiminin bilim sözde-bilim ayrımına yönelik tartışma düzeylerini geliştirmeleri söz konusu olabildiği gibi, ilgili tartışmaların da akademik düzeyi arttırabileceği hipotezinden yola çıkılan çalışmada ön test ve son testler değerlendirmeye alınmıştır. Yapılan değerlendirmede bilim sözde-bilim ayrımı bağlamında kurgulanmış bir öğretim süreciyle katılımcıların ilgili akademik bilgi düzeylerinin anlamlı bir şekilde geliştirilebileceği gözlenmiştir.

McLean ve Miller (2010) öğrencilerin para-normal inanışlarını azaltmaya ve eleştirel düşünme becerilerini geliştirmeye yönelik yaptıkları çalışmada deney ve kontrol grupları oluşturmuş, deney 
grubuna bilim ve sözde-bilim ayrımına, kontrol grubuna ise eleştirel düşünme becerilerine yönelik eşit süreli eğitim vermişlerdir. Sonuçta her iki grubun da para normal inanışlarının düştüğü ve eleştirel düşünme becerilerinin geliştiği görülmekle birlikte deney grubunda belli para normal inanışları ayırt edebilmenin anlamlı derecede olumlu yönde farklıık gösterdiği belirlenmiştir. Dolayısıyla öğrencilerin bilim sözde-bilim ayrımına yönelik becerileri ile eleştirel düşünme becerilerinin birbirini desteklediği söylenebilir.

Bu çalışmalar dışında fen eğitimi düzeyinde yapılan çalışmaların genellikle öğrencilerin ve öğretmen adaylarının sözde-bilimsel inanışlarını tespit etmeye yönelik olduğu (Aarnio ve Lindeman, 2005; DeRobertis ve Delaney, 1999; Eve ve Harrold, 1986; Goode, 2002; Impey, Buxner ve Antonellis, 2012; Losh ve Nzewke, 2011; Lundström, 2007; Martin, 1994; Morhed, 2000; Akt. Lunström, 2011; Nickell, 1992; Peoa ve Paco, 2004; Preece ve Baxter, 2000; Rice, 2003; Sugarman, Impey, Buxner \& Antonellis, 2011; Turgut vd., 2010; Turgut, 2009 söylenebilir.

\subsection{Amaç}

Araştırmanın amacı, öğrencilerin bilim sözde-bilim ayrımına yönelik algılarını tespit etmek, planlanan argümantasyon tabanlı öğrenme etkinlikleri ile öğrencilerin bu algılarını ve bu bağlamda gerçekleştirilen tartışma becerilerini tespit etmektir. Belirlenen bu amaç doğrultusunda düzenlenen ana problem ve alt problemler aşağıdaki gibidir:

Yedinci sınıf öğrencilerinin bilim sözde-bilim ayrımına yönelik görüşleri nelerdir?

a) Öğrencilerin bilimsel bilgi ölçütleri nelerdir?

b) Bilimsel bilginin kaynakları nelerdir?

c) Öğrencilerin sözde-bilimsellik ölçütleri nelerdir?

\section{YÖNTEM}

Bu çalışmada, katılımcıların bilimsel bilgiye dair algılarını arka planda yatan gerekçelerle ortaya koyabilmek için araştırmacının katılımcı role sahip olduğu ve doğal ortama duyarlı olan nitel paradigma seçilmiştir.

Bu çalışmada nitel araştırma yöntemlerinden, derinlemesine ve ayrıntılı bir kavrayışa sahip olmadığımız olgulara odaklanan, yaşadığımı dünyada olaylar, deneyimler, algılar, yönelimler, kavramlar ve durumlar gibi çeşitli şekillerde karşımıza çıkan olguları araştırmayı amaçlayan fenomenoloji (olgubilim) (Yıldırım ve Şimşek, 2011) kullanılmıştır.

Çekmez, Yıldız ve Bütüner'e (2012) göre, fenomenolojik yaklaşımın merkezinde kişisel deneyimler yer almaktadır. Bu yaklaşım bireyin kişisel dünya görüşü ile olayları yorumlamasıyla yani bireyin fenomenolojisiyle ilgilenir. Bu tip yaklaşımda araştırmacı, katılımcılara üzerinde çalışılan fenomene ilişkin ön-bilgi sunmaz, fenomeni bireyin algıladığı şekilde anlamaya çalışır. Fenomenolojik yaklaşımda araştırmacı, araştırmaya katıım gösteren bireylerin davranışlarını incelemekle beraber katılımcıların ilgili fenomene yönelik olarak kendilerini ve dünyalarını nasıl gördüklerini de inceleyerek insan doğası hakkında bilgiler öğrenebileceğini düşünür. Yıldırım ve Şimşek'e (2011) göre, fenomenoloji araştırmaları nitel çalışmaların doğasına uygun olarak kesin ve genellenebilir sonuçlar ortaya koymayabilir, ancak bir olguyu daha iyi tanımamıza ve anlamamıza yardımcı olacak örnekler, açıklamalar ve yaşantılar ortaya koyabilir. Bu yönüyle hem bilimsel alanyazına hem de uygulamaya önemli katkılar getirebilir. Bu çalışmada sözde-bilimsel fenomenler etrafında katıımcıların vakaları argümanlarla yorumlaması araştırılmıştır.

Fenemolojik araştırmalarda yapılandırılmış yada yarı yapılandııımış görüşmeler kullanılır. Katılımcılarla birden çok görüşülmesi derinlemesine veri toplamak için önemlidir. Görüşmelerin yüzyüze yapılması önerilir. Katılımcı sayısı 5 ile 25 kişi arasında değişir ve örneklem amaçsal örnekleme ile belirlenir (Güler, Halıcıoğlu ve Taşğın, 2015). Bu çalışmada sözde-bilimsel fenomenler etrafında katıımcıların vakalarının argümanlarla yorumlaması araştırılmıştır 


\section{1 Çalışma Grubu}

Çalışmanın örneklemini 2014-2015 Eğitim-Öğretim yılında, yedinci sınıfta öğrenim gören 8'i erkek, 16 'sı kız olmak üzere 24 öğrenci oluşturmaktadır. Araştırma yedinci sınıf "Bilim Uygulamaları" dersi kapsamında yapılmıştır. Bilim Uygulamaları dersi seçmeli ders olup, tercih eden öğrenciler tarafından seçilmektedir. Nitel araştırmaların doğasına uygun olan, hem olay ve olguları hem de bunların değişkenlik gösteren özelliklerini ortaya koyabilen amaçı örnekleme yöntemi olan tipik durum örneklemesi tercih edilmiştir (Yıldırım ve Şimşek, 2011).

\subsection{Veri Toplama Yöntemi}

Araştırmada veri toplama aracı olarak öğrenci görüşmeleri, Toulmin Argüman Modeli Şeması, Grup Tartışma Tutanağı kullanılmıştır. Araştırma süresince toplanan verilerin sınırlıı̆ını ortadan kaldırmak, geçerlik ve güvenirliğini arttırmak için veri çeşitlemesi (triangulation) yapılmıştır. Araştırmada kullanılan çalışma modeli Tablo 1 de gösterilmiştir.

Tablo 1. Çalışma modeli

\begin{tabular}{|c|c|c|c|c|c|c|}
\hline \multirow{3}{*}{$\begin{array}{l}\text { Uygulama } \\
\text { Öncesi }\end{array}$} & \multicolumn{5}{|c|}{ Uygulama Süreci } & \multirow{2}{*}{$\begin{array}{c}\text { Uygulama } \\
\text { Sonrası }\end{array}$} \\
\hline & 1.hafta & 2.hafta & 3.hafta & 4.hafta & 5.hafta & \\
\hline & Etkinlik 1 & Etkinlik 2 & Etkinlik 3 & Etkinlik 4 & Etkinlik 5 & \multirow{4}{*}{$\begin{array}{c}\text { Son } \\
\text { Görüşme }\end{array}$} \\
\hline \multirow[t]{3}{*}{$\begin{array}{l}\text { Ön } \\
\text { Görüşme }\end{array}$} & $\begin{array}{l}\text { Himalaya } \\
\text { Kaya } \\
\text { Tuzu }\end{array}$ & $\begin{array}{l}\text { Manyetik } \\
\text { Insanlar }\end{array}$ & $\begin{array}{l}\text { Astronomi- } \\
\text { loji }\end{array}$ & Refleksoloji & Numeroloji & \\
\hline & \multicolumn{5}{|c|}{ Toulmin Argüman Modeli Şeması } & \\
\hline & \multicolumn{5}{|c|}{ Grup Tartışma Tutanağı } & \\
\hline
\end{tabular}

Tablo 1 de görüldüğü gibi 5 hafta süresince "Himalaya Kaya Tuzu”, “Manyetik İnsanlar”, Astronomiloji" ve "Numeroloji" olmak üzere beş farklı etkinlik düzenlenmiş ve bu etkinlikler argümantasyon yöntemi kullanılarak derslerde işlenmiştir. Argümatasyon yönteminin uygulanması sürecince her etkinliğe 2 ders saati ayrıımıştır. Etkinlikler sözde-bilimsel alanın tanıtımını ya da sözde-bilimsel alanla ilgili haber kaynaklarını içeren metinlerden (Şekil 1'e bakınız) oluşmaktadır. Metin dışında sözde-bilimsel alanla ilgili öğrencilerin dikkatini çekmek ve argümantasyon sürecini çeşitlendirmek için etkinlik konusu ile ilgili video ya da slayt gösterimi yapılmıştır.

Her etkinliğin ilk dersinde etkinlik konusunu ve metinde geçen iddiaları öğrencilerin grup içerisinde tartışması ve "grup tartışma tutanağı"nı doldurması sağlanmıştır. Grup içerisinde öğrenciler etkinlik konusunun bilimselliğine dair yürüttükleri tartışma süreci sonrasında ikinci derste sınıf içi argümantasyon sürecine katılmaları sağlanmıştır. Sınıf içi argümantasyon süreci video kaydına alınmıştır. Bu kaydın yapılmasındaki amaç, öğrencilerin uygulama sırasında bilimin hangi boyutlarına vurgu yaptıklarını, argümantasyon sürecinde hangi öğeleri ne düzeyde kullandıklarını öğrenmek için veri çeşitlemesi yapılmasıdır. Tartışma sürecinin bitiminde öğrencilerin bireysel olarak Toulmin Argüman Modeli Şemasını doldurarak ders sonunda araştırmacıya teslim etmeleri sağlanmıştır.

\subsubsection{Görüşmeler}

Araştırmada öğrencilerin uygulama öncesi ve sonrasındaki bilimsellik ve sözde-bilimsellik ölçütlerini açı̆̆a çıkarmak amacıyla örneklem içerisinden rastgele (random) seçilen 10 öğrenci ile ön ve son görüşmeler gerçekleştirilmiştir. Birden çok görüşme yapılması ile öğrencilerin süreç içerisinde bilimsel bilgi ölçütlerindeki gelişim ya da değişimin tespit edilmesi amaçlanmıştır. Ayrıca birden fazla görüşme yapılması araştırmacının görüşmeler sırasında ulaştığı açıklama ve anlamlandırmaları görüşülen kişiye teyit ettirme fırsatı sunması sebebiyle araştırmanın geçerliliğini ve güvenilirliğini arttırmaktadır (Yıldııım ve Şimşek, 2011). 
Veriler yarı yapılandırılmış görüşme tekniğiyle toplanmıştır. Yarı yapılandırılmış görüşmeler genellikle 10-15 dk sürecek şekilde hazırlanır (Güler, Halıcıoğlu ve Taşğın (2015). Araştırmada kullanılan görüşme soruları araştırmacı tarafından ilgili alan yazının taraması yapılarak hazırlanmış ve uzman görüşü alınarak kapsam geçerliliği gözden geçirilmiş sorulardan oluşturulmuştur. Görüşmeler öncesinde 5 yedinci sınıf öğrencisi ile pilot uygulama yapılarak soruların yeniden yapılandırılması sağlanmıştır.

Görüşme soruları bilimsellik ölçütleri (criteria for scientific knowledge), sözde bilimsellik ölçütleri (criteria for pseudoscientfic knowledge), bilimsel bilginin kaynakları, bilim-sözdebilim (pseudoscience) ayrımı becerisi olmak üzere dört alt başlıkta toplanmış 10 sorudan oluşmaktadır (Tablo 2). Öğrencilerden önceden randevu alınarak bire bir görüşme yapılmıştır. Görüşme yapılacak öğrencilerden ve velilerinden gerekli izin alındıktan sonra ses kayıt cihazı kullanılıp veriler toplanılmıştır. Görüşmeler yaklaşık 15 dakika sürmüş olup, sessiz ve dikkat dağıtııılardan uzak olması sebebiyle görüşmeler okul kütüphanesinde gerçekleştirilmiştir. Her bir katılımcıya "öğrenci 1", "öğrenci 2" şeklinde bir kod verilmiştir.

Tablo 2. Görüşme soruları yapılandırması

\begin{tabular}{|c|c|c|}
\hline Soru & Soru & Kriter \\
\hline 1 & "Bilimsel bilgi" den ne anlıyorsun? Sana neyi çağrıştırıyor? & Bilimsellik \\
\hline 2 & $\begin{array}{l}\text { Bir bilginin bilimsel olduğuna nasıl karar verirsin? Sence bilimsel } \\
\text { bilginin özellikleri nelerdir? }\end{array}$ & Bilimsellik \\
\hline 3 & Bilimsel olan bilgi ile bilimsel olmayan bilgiyi nasıl ayırt edersin? & $\begin{array}{l}\text { Bilim sözde-bilim } \\
\text { ayrımı becerisi }\end{array}$ \\
\hline 4 & Sence bilginin kaynakları nelerdir? & $\begin{array}{l}\text { Bilginin } \\
\text { kaynakları }\end{array}$ \\
\hline 5 & Sana göre doğru ve güvenilir bilginin ölçütü ne olmalıdır? & Bilimsellik \\
\hline 6 & Sence batıl inanış nedir? & Sözde-bilimsellik \\
\hline 7 & $\begin{array}{l}\text { Batıl inanışların özellikleri nelerdir? Bir inanışı batıl olarak kabul } \\
\text { etmen için hangi özelliklere sahip olması gerekir? }\end{array}$ & Sözde-bilimsellik \\
\hline \multirow[b]{2}{*}{8} & Batıl inanışların var mı? & \multirow{3}{*}{ Sözde-bilimsellik } \\
\hline & $\begin{array}{l}\text { Evet ise; hangi inanışlarının batıl olduğunu düşünüyorsun? } \\
\text { Hayır ise; çevrendeki insanların sahip olduğu batıl inanışlar var mı? } \\
\text { Var ise, neler? }\end{array}$ & \\
\hline & $\begin{array}{l}\text { Aşağıda verilen kavramları sana göre uygun olan sütuna yerleştirir } \\
\text { misin? }\end{array}$ & \\
\hline 9 & $\begin{array}{l}\text { Astroloji, ufoloji, psikoloji, refleksoloji, tıp, astronomi, iridoloji, } \\
\text { biyoloji, sosyoloji, alternatif tıp, numeroloji, el okuma, jeoloji, } \\
\text { antropoloji, tarih, kahinlik, kozmik bilim (kozmik taşlar, şifalı } \\
\text { taşlar...) (Bilim dalı/Fikrim yok/Bilim Dalı Değil) }\end{array}$ & $\begin{array}{l}\text { Bilim sözde-bilim } \\
\text { ayrımı becerisi }\end{array}$ \\
\hline 10 & $\begin{array}{l}\text { Aşağıda bazı haber başsıkları verilmiştir. Bunlardan bilimsel bilgi } \\
\text { taşıdığını düşündüklerinizin yanına ' } X \text { ' işareti koyunuz. }\end{array}$ & $\begin{array}{l}\text { Bilim sözde-bilim } \\
\text { ayrımı becerisi }\end{array}$ \\
\hline
\end{tabular}

\subsubsection{Grup Tartışma Tutanağı}

Her etkinlik için ayrı ayrı geliştirilen ve etkinliğe yönelik sorular içeren grup tartışma tutanakları (Tablo 3) katılımcıların kendi aralarında fikir birliğine varma amaçlı tartışma süreci yaşamasını sağlaması açısından önem taşımaktadır.

Uygulama sırasında öğrencilerin altışarlı dört grup oluşturması sağlanmış ve her etkinlik için öncelikle grup içi argümantasyon süreci gerçekleştirilmiştir. Grup içerisinde gerçekleştirilen argümantasyon süreci katılımcılar tarafından her ders için ayrı düzenlenmiş olan grup tartışma 
tutanağına kaydedilmiştir. Her ders öğrencilerin etkinlikle ilgili öncelikle grup içerisinde tartışması için 15 dakikalık zaman verilmiş ve bu tartışma sonuçlarını grup tartışma tutanağına işlemeleri istenmiştir. Grup tartışma tutanağı öğrencilerin grup içi tartışma sürecini yönlendirici sorular içermektedir. Böylece öğrencilerin grup içi argümantasyon sürecini sınıf içi argümantasyon sürecine taşımaları sağlanmıştır.

\section{Biyoenerji ders etkinliği \\ MIKNATIS ADAM'IN SIRRI ÇÖZÜLEMEDi}

Nevşehir'in Avanos ilçesinde yaşayan 51 yaşındaki Halis Ateş, vücuduna, göğsüne ve sırtına kızının yardımı ile tatlı ve yemek kaşıkları, tencere, cam ve cep telefonu yapıştırıyor. Türkiye'de "Mıknatıs Adam" olarak tanınan işçi emeklisi Halis Ateş, geçtiğimiz yıl vücuduna 75 metal kaşık yapıştırarak dünya rekoru da kırmıştı. Vücuduna kaşıkların yanı sıra ütü, tencere, cep telefonu, kül tablası gibi eşyaları yapıştırarak şov yapan Halis Ateş, 15 yıl önce kulak burun boğaz doktoruna muayeneye gittiğinde dinleme cihazının vücuduna yapışmasıyla doktorunun durumu fark ettiğini söyledi. Kendisinde biyoenerji olduğunun Amerikalı doktorlar tarafından söylendiğini belirten Ateş, "Babamda da bu özellik vardı. Metal ve plastik vücuduna yapışıyordu. Ama ben o zamana kadar hiç uğraşmadım. Bizdeki genetik bir özelliktir. Benden de kızlarıma geçti. Çocuklarımızda daha fazla bulunuyor. Bana Amerika'dan bir doktor geldi, araştırma yaptı. Biyoenerjimin olduğunu söyledi" dedi.

\section{GRUP TARTIŞMA TUTANAĞI}

Aşağıdaki soruları grup içerisinde tartışarak yanıtlayınız.

1-Videoda izlediğiniz ve yukarıda okuduğunuz haberde adı geçen Halis Ateş' in sunduğu görsel ve sözel iddiaları not ediniz.

2-Not ettiğiniz iddiaları bilimsel gerçekliğe uygun olan ve olmayan olarak sınıflandırınız.

3-Iddiaları sınıflandırırken hangi dayanakları kullandınız? Her iddiayı hangi gerekçelerle bilimsel/bilimsel olmayan olarak değerlendirdiğinizi yazınız ve sınıf ortamında sununuz.

4-Manyetik insanların varlığına gerçekten inanıyor musunuz? Bu insanların üzerlerinde farklı cisimleri tutabilmelerinin sebepleri neler olabilir? Bir sonraki ders sınıf ortamında görüşlerinizi sunmak üzere düşününüz.

\subsubsection{Toulmin Argüman Modeli Şeması}

Şekil 1. Örnek Grup Tartışma Tutanağı

Toulmin'in (1958) önerdiği "Argümantasyon Modeli" “iddia, veri ve gerekçelerini" belirtecekleri şekilde tablolaştırılarak katııımcılara dağıtılmıştır. Katılımcıların her ders için şemayı doldurması sağlanarak argümantasyon becerilerinin incelenmesi amaçlanmıştır.

\subsection{Verilerin Analizi}

Verilerin çözümlenmesi sırasında nitel veri kaynakları için ayrı çözümleme yolları geliştirilmiştir. Nitel verilerin çözümlenmesi, bilim sözde-bilim ayırımı becerileri ve argümantasyon süreç becerileri olmak üzere iki farklı bağlamda gerçekleştirilmiştir.

Verilerin çözümlenmesi sürecinde elde edilen veriler, içerik analizi yöntemiyle incelenmiş ve yorumlanmıştır. Içerik analizinde temel amaç, toplanan verileri açıklayabilecek kavramlara ve ilişkilere ulaşmaktır. İçerik analizi kapsamında ilk aşamada görüşme verileri kodlanmıştır. Kodlama aşamasında, elde edilen veriler incelenir, anlamlı bölümlere ayrılır ve her bir bölümün kavramsal 
olarak ne anlama geldiği bulunmaya çalışılır (Yıldırım ve Şimşek, 2011). Bu araştırmada veriler toplanmadan önce hem temalar hem de temalar altında yer alabilecek kavramlar düzeyinde bir kod listesi oluşturulmuş, bu sayede toplanan verilerin kodlanma işlemi daha kolay gerçekleştirilmiştir. Veri analiz sürecinde kodlama işlemi tekrar tekrar gerçekleştirilmiş, gerekli değiştirme ve geliştirmeler söz konusu olmuştur. Veri analizinin son aşamasında ise elde edilen bulgular açıklanmış, yorumlar ve sonuçlar sunulmuştur. Araştırma verilerinin sunumunda katılımcılara verilen kodlardan yararlanılmış ve bazı görüşlerden doğrudan alıntılar yapılarak yorumlar desteklenmiştir. Görüşme soruları dört farklı tema altında iincelenmiştir. Bunlar bilimsellik ölçütü (1, 2, 3, 4 ve 5. sorular), bilimsel bilginin kaynakları (4. soru) ve sözde-bilimsellik Ölçütleri (3, 6, 7 ve 8. sorular) ve bilim sözde-bilim ayrımı becerisi (9 ve 10. sorular).

Verilerin çözümlenmesi sürecinde ayrıca özgün görüş ve düşünceleri yansıtacak şekilde doğrudan alıntılara da yer verilmiştir. Bunlar araştırma verilerinin geçerlik ve güvenirliğini artıracak uygulamalar olarak kabul edilebilir. Verilerin çözümlenmesi sonucu; bulgular kendi içinde tutarlı, anlamlı ve daha önceden oluşturulan kavramsal çerçeve ve kuramlarla uyumlu şekilde çıkmıştır. Bu durum araştırmanın iç geçerliliğini sağlamaktadır.

Görüşme sonunda katılımcıya araştırmacı öğrendiklerini özet olarak aktararak kendi algısının aktarılan verilerin doğru yansıtıp yansıtmadığı sorularak dış güvenirlik sağlanmıştır. Ön ve son görüşmeler için oluşturulan kod ve kategoriler iki araştırmacı tarafından oluşturularak yapılan kodlamalar karşılaştırılmış ve kodlamalar arası uyuşmanın \%87 olduğu görülmüştür.

\section{BULGULAR}

Bu kısımda öğrencilerin bilimin kaynakları ve bilim sözde-bilim ayrımına yönelik görüşlerinin tespiti için ön ve son görüşmelerden elde edilen veriler incelenmiş ve diğer veri toplama araçları ile toplanan verilerle desteklenmiştir.

\subsection{Yedinci Sınıf Öğrencilerinin Bilimsellik Ölçütleri}

Bu kısımda öğrencilerin ön ve son görüşme ifadeleri incelenmiş ve diğer veri toplama araçları ile toplanan verilerle desteklenmiştir.

Tablo 3. Öğrencilerin bilimsellik ölçütlerine yönelik ön ve son görüşme karşılaştırılmalı bulguları

\begin{tabular}{|c|c|c|c|c|c|}
\hline Kategori & Kod & $f$ & Ön-görüşme & $f$ & Son-görüşme \\
\hline Evrensellik & $\begin{array}{l}\text { Tüm bilim } \\
\text { dünyasında kabul } \\
\text { görme } \\
\text { Herkesçe kabul } \\
\text { edilme } \\
\text { Her kaynakta aynı } \\
\text { şekilde ifade } \\
\text { edilme }\end{array}$ & 3 & $\begin{array}{l}\text { “....Tüm dünyaca kabul edilen } \\
\text { bilgilerdir. Herkes tarafından kabul } \\
\text { edilmesi gerekir ve herkesin bu } \\
\text { bilgiyi bilmesi gerekir. Bilimsel } \\
\text { olmayan bilgi tüm dünyaca kabul } \\
\text { edilmeyen, her ülkede farklı } \\
\text { olandır. Tüm dünyaca kabul } \\
\text { edilmezse bilimsel olmaz.” } \\
\text { Öğrenci } 1\end{array}$ & 7 & $\begin{array}{l}\text { “Herkesçe kabul edilmiş olması } \\
\text { gerekir. Mesela Dünya, Güneş } \\
\text { sisteminde üçüncü sıradadır. Bu } \\
\text { herkes için aynı.” Öğrenci } 5\end{array}$ \\
\hline $\begin{array}{l}\text { Otorite Görüşü } \\
\text { (Söyleyenin } \\
\text { Niteliği) }\end{array}$ & $\begin{array}{l}\text { Bilim insanı } \\
\text { görüşü } \\
\text { Güvenilir kaynak } \\
\text { Uzman kişiler } \\
\text { Bilimsel kurumlar }\end{array}$ & 1 & $\begin{array}{l}\text { “Uzman olan kişilerin söylemiş } \\
\text { olması gerekli. Bir uzman insan } \\
\text { vardır, bir de o an kafasındakini çat } \\
\text { diye söyleyen vardır. Ben uzman } \\
\text { insana güvenirim. Çünkü en iyi o } \\
\text { bilir, o konu hakkında daha çok } \\
\text { bilgisi vardır." Öğrenci } 2\end{array}$ & 3 & $\begin{array}{l}\text { "Bazı bilim insanları tarafından } \\
\text { onaylanmış mı bakarım..... Kim } \\
\text { tarafından söylendiği önemli. } \\
\text { Söyleyen kişi konu ile ilgili ne kadar } \\
\text { birikime sahip, bilgi düzeyi ne, } \\
\text { kendinden emin mi, sorulan } \\
\text { soruları rahatça yanıtlayabiliyor mu } \\
\text { falan.” Öğrenci } 2\end{array}$ \\
\hline Bilimsel Yöntem & Bilimsel çalıșma & 1 & $\begin{array}{l}\text { “Bilimsel bilgi üzerinde araştırma } \\
\text { yapılan, oturup incelenen, alalade } \\
\text { karar verilmeyen, araştırma } \\
\text { yapıldıkça o bilgi üzerinde daha çok } \\
\text { bilgiye ulaşmak." Öğrenci } 2\end{array}$ & 2 & $\begin{array}{l}\text { "Bilimsel olması için araştırılması ve } \\
\text { veri toplanması, deneyler, } \\
\text { gözlemler içermesi gerekir. Bilimsel } \\
\text { olmayan bilgi çok detaylı } \\
\text { araştırılmamıştır, mantığa aykırıdır, } \\
\text { fazla veri-gerekçe yoktur, sadece } \\
\text { iddia taşır." Öğrenci } 6\end{array}$ \\
\hline
\end{tabular}




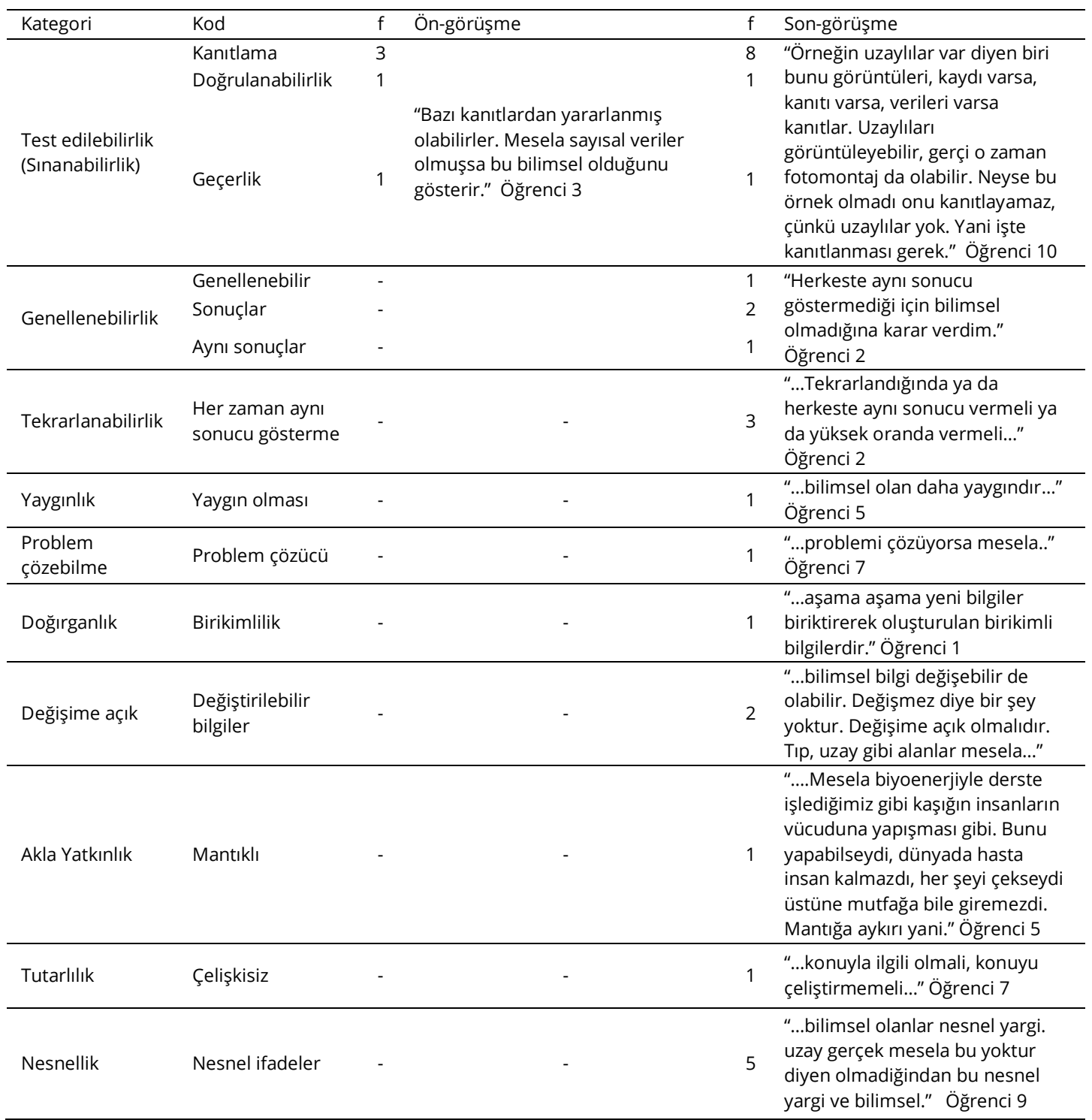

Tablo 3 incelendiğinde etkinliklerin bitiminde gerçekleştirilen son görüşmelere, öğrencilerin ön görüşmelerde bilimsellik değerlendirmesi yaparken kullandıklarını ifade ettikleri dört ölçütün (evrensellik, otorite görüşü, bilimsel yöntem, test edilebilirlik) ifade edilme sıklığı artarak taşınırken; "Genellenebilirlik", "Tekrarlanabilirlik", "Yaygınlık", "Problem Çözebilme”, "Doğurganlık”, "Değişime Açıklık”, "Akla Yatkınlık", “Tutarlıık” ve "Nesnellik” gibi ölçütlerin de eklendiği görülmektedir.

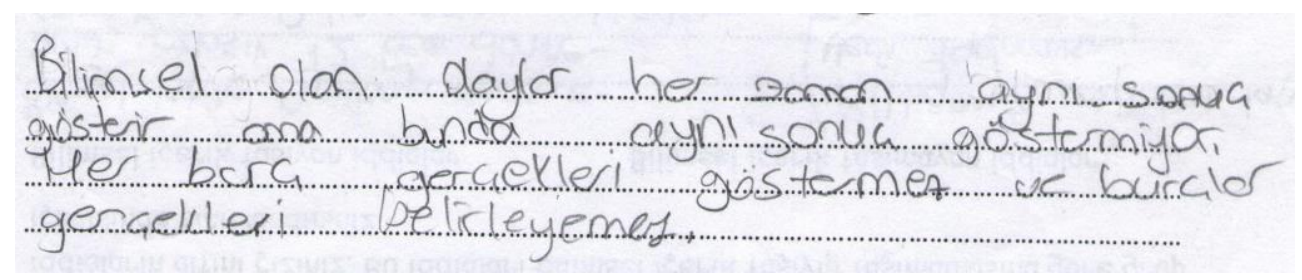

Etkinlik 3-grup tartışma tutanağı-Grup 4 


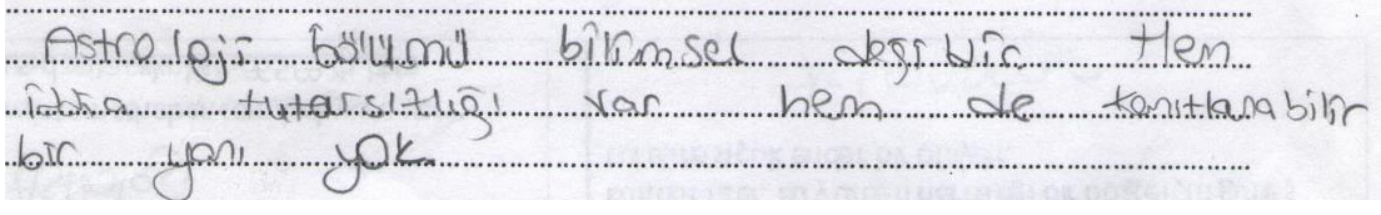

Etkinlik 3-grup tartışma tutanağı-Grup 2

\begin{tabular}{|c|c|c|}
\hline IDDIA & VERI & GEREKÇE \\
\hline $\begin{array}{l}\text { Manyetiklik goicu } \\
\text { yokitur }\end{array}$ & $\begin{array}{l}\text { Cunkú eger manyer } \\
\text { fiklik gieu olsa } \\
\text { Sadege metal ocker- }\end{array}$ & $\begin{array}{l}\text { Plastik ve cam } \\
\text { cektigin iddia } \\
\text { ediger. }\end{array}$ \\
\hline
\end{tabular}

Etkinlik 4- Toulmin argüman modeli-Öğrenci 23

\subsection{Bilimsel Bilginin Kaynakları}

Bu kısımda öğrencilerin bilimsellik ölçütlerini tespit etmek amacıyla bilimsel bilgiye ulaşırken kullandıkları kaynaklara yer verilmiştir.

Tablo 4. Bilimsel Bilginin Kaynaklarına Yönelik Ön ve Son Görüşme Bulguları

\begin{tabular}{lcc}
\hline Kaynak & Ön Görüşme (f) & Son Görüşme (f) \\
\hline Ansiklopedi & 6 & 6 \\
Internet & 7 & 3 \\
Kitap & 5 & 5 \\
Uzman kişiler & 1 & 5 \\
Büyükler & 1 & - \\
Öğretmenler & 1 & - \\
Okumuş insanlar & 1 & - \\
Bilimsel dergiler & 2 & 3 \\
Araştırma sonuçları & 1 & 1 \\
Bilgievi & 1 & - \\
Bilimsel kurumlar & 1 & 3 \\
Belgesel Kanalları & - & 1 \\
Haberler & - & 1
\end{tabular}

Tablo 4. incelendiğinde ön görüşmelerde ilgili soruya verilen cevaplardan 11 farklı kaynağa ulaşıııken; son görüşmelerde dokuz farklı kaynaktan söz edilmiştir. "Ansiklopedi"yi güvenilir bir kaynak olarak ifade eden öğrenci sayısı değişmezken; "internet" kaynağından bahseden öğrenci sayısı düşmüştür. Ön görüşmelerde öğrencilerin 7'si interneti güvenilir bulurken, bu sayı son görüşmelerde 3 öğrenci ile sınırlı kalmıştır. Bazı öğrenciler son görüşmeler sırasında interneti güvenilir bulmadığını şu şekilde ifade etmiştir:

“...Aslında internet çok güvenilir bir ağ değil. Çünkü herkes kendi bakış açısına göre yorumlar yapıyor, asıl bilgi ile bu yorumlar karışıyor. Biz hangisini seçeceğiz çok emin olamıyorum. Ansiklopedi olabilir. Onun bir basımı var, araştırılarak varılmış bilgiler var. Kafasına göre bilgi verilmemiş. Veriler var." Öğrenci 3 
“internette araştırılan her şey doğru olmuyor. Çünkü insanlar yazıyor kafasına göre. Onun bilimsel olup olmadığını da içindeki verilerden, dayanaklardan anlarım. Bunun dışında kitaplar, ansiklopediler, dergiler de bilgi kaynağı. Bilim dergilerinde mesela kanıtını, gözlem, deney falan verdiği için güveniyorum. Ama onun dışında kitap deyince astroloji kitabı da var. Her kitap güvenilir değil. O da sadece yıldızların konumunu falan anlatıyor. Bilimsel dayanağı olmamasına rağmen bilimselmiş gibi gösteriyor. Öyle şeyleri değil de önemli kurum ve kişilerin dergileri ve ansiklopedileri olabilir. Onlarda kanıt ve dayanak olduğundan daha güvenilir." Öğrenci 10

Öğrencilerin ifadelerini incelediğimizde internetin güvenilir bir kaynak olmadığını ifade ettiklerini görmekteyiz. Öğrenci 10'un ifadesi incelendiğinde ise internet için geçerli şüphenin basılı kitaplar için de geçerli olduğu söylenebilir. Öğrenci bilginin kaynağı yerine, kaynağın sunduğu ifadelere vurgu yapmıştır. Bir kitap ya da internet sitesinin güvenilirliğini belirlemenin, kaynağın sunduğu bilgilerin dayanağına bakılarak mümkün olabileceğini belirtmiştir.

Tablo 4. incelendiğinde ön görüşmelerde bazı öğrenciler tarafından güvenilir kaynaklar olarak belirtilen "büyükler", "öğretmenler" ve "okumuş insanlar" ifadelerine son görüşmelerde rastlanmazken; ön görüşmelerde geçmeyen "belgesel kanallari" ve "haberler" son görüşmelerde güvenilir bilgi kaynaklari olarak ifade edilmiştir. bunun dişinda "uzman kişiler", "bilimsel kurumlar" ve "bilimsel dergiler" kaynaklarinin güvenilir olduğunu ifade eden öğrenci sayısı, son görüşmelerde ön görüşmelere göre artış göstermiştir.

\section{3 Öğrencilerin Sözde-Bilimsellik Ölçütleri}

Bu kısımda öğrencilerin görüşme sorularında yer alan "sözde-bilimsellik ölçütlerini" tespite yönelik sorulara verdikleri yanıtlar incelenmiş ve ön-son görüşme karşılaştırması yapılmıştır.

Tablo 5. Öğrencilerin sözde-bilimsellik ölçütlerine yönelik ön ve son görüşme karşılaştırılmalı bulgu

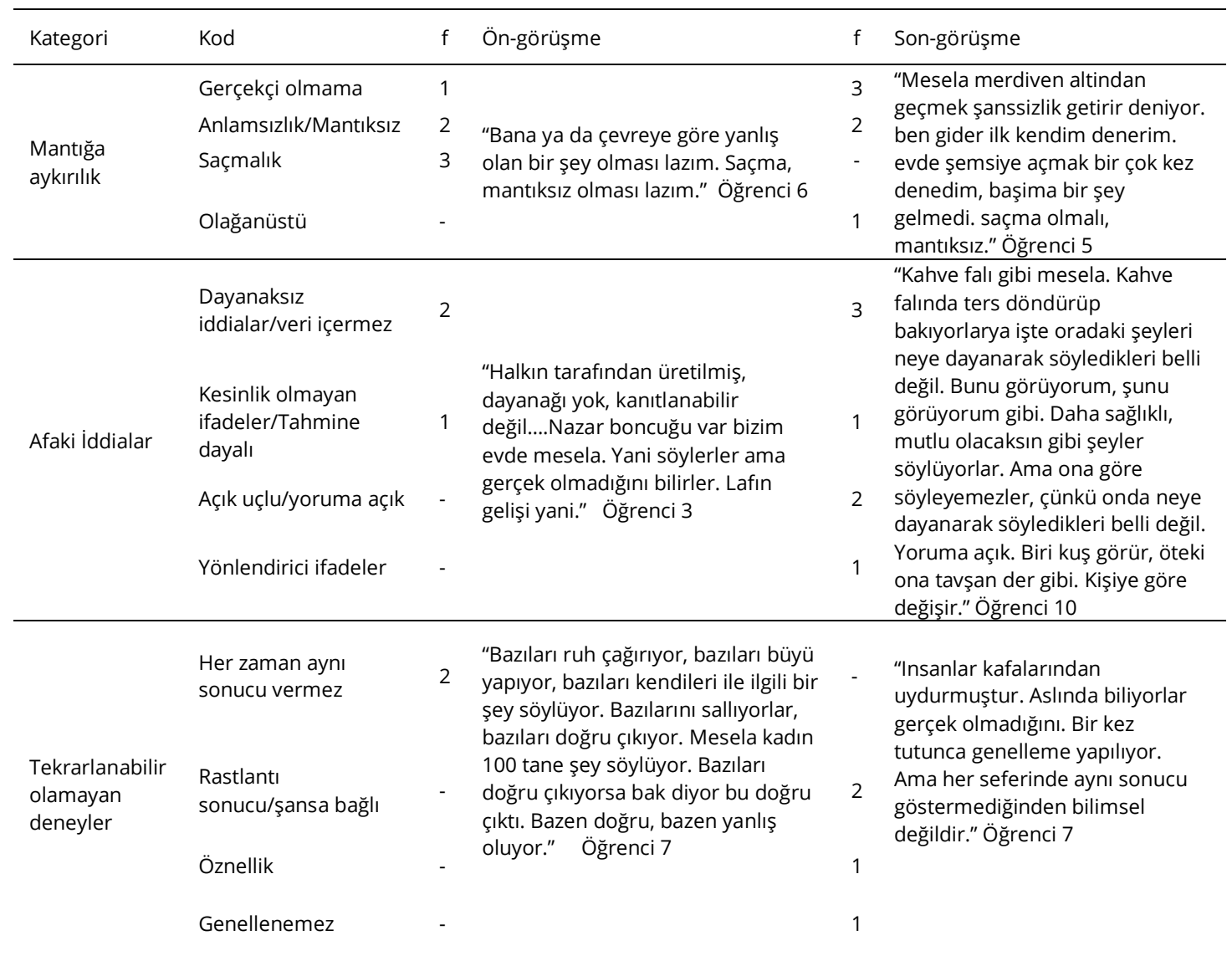




\begin{tabular}{|c|c|c|c|c|c|}
\hline Kategori & Kod & $f$ & Ön-görüşme & $f$ & Son-görüşme \\
\hline \multirow{4}{*}{$\begin{array}{l}\text { Bilimde yer } \\
\text { almama }\end{array}$} & $\begin{array}{l}\text { Bilimsel olarak } \\
\text { açıklanmama }\end{array}$ & 1 & $\begin{array}{l}\text { “Gece tırnak kesilmez örneğin. Çok } \\
\text { saçma. Bilimsel bir şeye }\end{array}$ & 2 & $\begin{array}{l}\text { “Okumuş insanların yapmayacağı } \\
\text { şeyler olmalı, bilimde yeri }\end{array}$ \\
\hline & & & dayanmıyor yani. Gerçek bir & & olmamalı, herkes inanmayacak o \\
\hline & Billimsellik taşımaz & - & Bilimsel olarak açıklanmamıştır." & 2 & uzmanların ismi geçmez." \\
\hline & Araştırma içermez & - & Öğrenci 10 & 1 & Öğrenci 1 \\
\hline \multirow{4}{*}{$\begin{array}{l}\text { Belirsiz } \\
\text { kaynak }\end{array}$} & Kaynak belirtmez & - & & & $\begin{array}{l}\text { “insanlar tarafından uydurulmuş } \\
\text { inanışlar. İnsanlar gerçekleştiğini } \\
\text { düşünüyor, ama aslında onlar o }\end{array}$ \\
\hline & & & & & inanışa göre davrandıkları için \\
\hline & & & & & gerçek olmuş gibi gözüküyor. \\
\hline & Kulaktan dolma & - & & & $\begin{array}{l}\text { İnsanların kendi inanışları } \\
\text { doğrultusunda ortaya çıkan } \\
\text { şeyler." Öğrenci } 3\end{array}$ \\
\hline \multirow{2}{*}{$\begin{array}{l}\text { Akla değil } \\
\text { inanaca } \\
\text { yönelik }\end{array}$} & İnanmaya bağlı & - & & 1 & “Kaynağı olmaz bu şeylerin...” \\
\hline & İnanışa bağlı & - & & 2 & Öğrenci 1 \\
\hline
\end{tabular}

Görüşme sorularından 9 ve 10. sorularda öğrencilerden sınıflama yapmaları istenmiştir ve bu sorularla bilim sözde-bilim ayrımına yönelik bilgileri açığa çıkarmak amaçlanmıştır. 9. soruda öğrencilere bazı sözde-bilimsel kavramlar verilmiş ve bu kavramların çalışma alanları ile ilgili basılı bir bilgilendirme yapılmıştır. Öğrencilerden bu alanları bilim dalı/bilim dalı değil/fikrim yok kategorilerinden birine yazmaları istenmiştir. Tema 4 kapsamında bu yanıtlar incelenmiştir.

Tablo 6. Öğrencilerin Sözde-bilimsel Alanlara Yönelik Tahminleri Ön ve Son Görüşme Bulguları

\begin{tabular}{lcccccc}
\hline \multirow{2}{*}{ Kavram } & \multicolumn{2}{c}{ Bilim Dalı } & \multicolumn{2}{c}{ Bilim Dalı Değil } & \multicolumn{2}{c}{ Fikrim yok } \\
& $\begin{array}{c}\text { Önüşme } \\
\text { (f) }\end{array}$ & $\begin{array}{c}\text { Son } \\
\text { görüşme (f) }\end{array}$ & $\begin{array}{c}\text { Ön } \\
\text { görüşme (f) }\end{array}$ & $\begin{array}{c}\text { Son } \\
\text { görüşme (f) }\end{array}$ & $\begin{array}{c}\text { Ön } \\
\text { görüşme } \\
(\mathrm{f})\end{array}$ & $\begin{array}{c}\text { Son } \\
\text { görüşme } \\
(\mathrm{f})\end{array}$ \\
\hline Astroloji & 7 & 2 & 2 & 7 & 1 & 1 \\
Ufoloji & 10 & 3 & 0 & 6 & 0 & 1 \\
Refleksoloji & 3 & 5 & 4 & 4 & 3 & 1 \\
İridoloji & 6 & 1 & 2 & 9 & 2 & 0 \\
Alternatif tıp & 3 & 4 & 3 & 5 & 4 & 1 \\
Numeroloji & 3 & 0 & 4 & 10 & 3 & 0 \\
El okuma & 1 & 0 & 8 & 10 & 1 & 0 \\
Kahinlik & 0 & 0 & 6 & 8 & 4 & 2 \\
Kozmik bilim & 7 & 1 & 2 & 8 & 1 & 1 \\
\hline
\end{tabular}

* Bir öğrenci birden fazla kategoriye uygun cevaplar vermiştir. $(n=10)$

Öğrencilerden 10. soruda ise bazı haber başlıklarından onlarda bilimsellik izlenimi oluşturanları işaretlemeleri istenmiştir. Ön ve son görüşmelerde öğrencilerin bu soru ile ilgili işaretlemeleri aşağıda tablolaştırılmıştır:

Tablo 7. Öğrencilerin Haber Başlıklarına Yönelik Bilimsellik Tahminleri

\begin{tabular}{lcc}
\hline Haber Başlı̆̆ı & $\begin{array}{c}\text { Ön görüşme } \\
\text { Sıklık (f) }\end{array}$ & $\begin{array}{c}\text { Son görüşme } \\
\text { Sıklık(f) }\end{array}$ \\
\hline Ay'ın yüzeyinde su bulundu & 10 & 9 \\
UFO lar yine göründü & 8 & 2 \\
Bu yılın en şanslı burcu KOÇ & 2 & 0 \\
Yetişkinden kök hücre klonlandı & 8 & 10 \\
Doğum tarihiniz hayatınızı etkiliyor & 3 & 1 \\
\hline
\end{tabular}

* Bir öğrenci birden fazla kategoriye uygun cevaplar vermiştir. $(n=10)$ 


\section{SONUÇ, TARTIŞMA VE ÖNERILER}

Araştırmanın problemlerinden biri "7. sınıf öğrencilerinin bilim sözde-bilim ayrımına yönelik görüşleri nelerdir?" sorusu idi. Bu problem dahilinde gerçekleştirilen ön görüşmelerde öğrencilerin bilimsellikle ilgili bilgilerinin ve ifadelerinin sığ, sorgulamalarının yetersiz olduğu tespit edilmiştir. Bu tespit araştırmanın diğer problemi olan "Argümantasyon tabanlı öğrenme etkinlikleri ile öğrencilerin bilim sözde-bilim ayrımı becerisini geliştirmek mümkün müdür?" sorusunun araştırılmasının gerekliliğini ortaya koymaktadır. Bu problem dahilinde yürütülen argümantasyon süreci ile öğrencilerin süreç sonunda geliştirdikleri bilimsellik ve sözde-bilimsellik ölçütlerinin arttı̆̆ı görülmüştür. Süreç başında öğrencilerin "evrensellik", "otorite görüşü", "bilimsel yöntem", "test edilebilirlik" kategorileri altında belirttikleri kodlamalar artış göstermiştir. Bunun yanı sıra süreç sonunda geliştirilen "genellenebilirlik", "tekrarlanabilirlik", "yaygınlık", "problem çözebilme", "doğurganlık", "değişime açıklık", "akla yatkınlık", "tutarlıık", "nesnellik" gibi kategoriler altındaki ölçütler Thagard (1978), Derry (1999), Mahner (2007) ve Tutar (2014) gibi araştırmacıların literatürde yer verilen ölçütleri ile paralellik göstermektedir.

Süreç sonunda öğrenciler sözde-bilimsel alan ve haberlerle ilgili daha doğru sınıflandırmalar yapmıştır. Göze çarpan bulgulardan biri de "ufoloji" alanını öğrencilerin tamamı ön görüşmelerde bilim sınıfına dahil ederken, çoğunluğun süreç sonunda bu alanı bilim sınıfının dışına attıkları tespitidir. "Ufoloji" alanında süreçte herhangi bir etkinlik gerçekleştirilmemesine rağmen en büyük sapma bu alanla ilgili olmuştur. Bu bulgu öğrencilerin bilimsel sorgulamalarının gerçekleştirilen etkinlikler dahilinde kalmayıp genele yansıdığının önemli bir göstergesidir. Öğrenciler süreçte geliştirdikleri ölçütleri süreç sonunda farklı alanları değerlendirirken de kullanmıştır.

Öğrencilere bilginin kaynakları sorulduğunda son görüşmelerde ön görüşmelere göre farklı görüşler tespit edilmiştir. Öğrencilerin ifadelerini incelediğimizde internetin en güvenilir kaynak olduğu yönündeki ön görüşme sonuçlarının son görüşmelerde tersi yönde ifadelerle yer değiştirdiğini görmekteyiz. Bunun nedeni olarak da internette yer alan bazı bilgilerin bilimsel bir süzgeçten geçmeden ve kaynağı ifade edilmeden sunuluyor olmasını göstermişlerdir. İnternette birçok bilginin kim tarafından dile getirildiği ve neye dayanarak söylendiği bilinmediğinden güvenilir bir kaynak olamayacağı ifade edilmiştir. Bunun aksine ansiklopedi, kitap gibi yayin organlarinin basim öncesinde belli bir araştırma sürecinden geçtiği düşünüldüğünden güvenilirliğini koruduğunun ifade edildiği söylenebilir. Süreç içerisinde uygulanan etkinliklerdeki örnek vakaların internet kaynaklı olmasının ve geliştirilen bilimsellik ölçütlerinin bu yönde olumlu bir değişime sebep olduğu tahmin edilmektedir. Bunun aksine ansiklopedi, kitap gibi yayın organlarının basım öncesinde belli bir araştırma sürecinden geçtiği düşünüldügünnden güvenilirliğini koruduğunun ifade edildiği söylenebilir.

Süreç sonunda öğrencilerin süreç başında kurdukları sığ ifadeler yerine daha açıklayıcı, geniş, kapsamlı, net ve gelişmiş ifadeler kullandıkları da görülmektedir. Ders içi yürütülen bilim sözdebilim odaklı argümantasyon süreci öğrencilerin bilimsel tartışma ve bilim sözde-bilim ayrımı becerilerini geliştirmiştir. Bu durumda yapılan araştırmada örneklemin argümantasyon beceri düzeyi ile bilim sözde-bilim ayrımı becerisi arasında destekleyici bir ilişki olduğu söylenebilir. Argümantasyon becerisi geliştikçe öğrencilerin bilimsel tartışma becerisi gelişmekte ve ayrım bağlamında daha güçlü tartışmalar yürütülerek bilim sözde-bilim ayrımı becerisinin gelişebileceği söylenebilmektedir.

"Astroloji" ders etkinliği öğrencilerin en yüksek düzeyde katılım gösterdiği ders etkinliği olarak tespit edilmiştir. Bu alanın medyada sıklıkla yer bulması ve günlük hayatta popüleritesinin olmasının bu duruma sebep olduğu söylenebilir. Aynı zamanda bu ders etkinliği biri bilim diğeri sözde-bilim olan astronomi ve astroloji alanlarının karşılaştırılmasını merkeze aldığından bilimsel ve bilimsel olmayan iddiaların karşılaştııılmalı argümantasyonu gerçekleştirilmiştir. Bu bağlamda karşılaştııılmalı olarak gerçekleştirilecek argümantasyon sürecinin daha sorgulayıcı bir ortam sunabileceği ve bilimin ne olup ne olmadığını ortaya koymada fayda sağlayacağı söylenebilir. Bilim 
sözde-bilim ayrımı etrafında geliştirilen bu şekilde karşılaştırmalı etkinliklerin yapılacak araştırmalarda ve fen müfredatlarında yer bulmasının etkili olabileceği tartışmaya açılabilir.

"Refleksoloji" etkinliği sırasında ise öğrenciler bu alanı ilk kez duyduklarını belirtmiş ve astroloji etkinliğinin tersine en düşük katılım bu etkinlik sırasında gerçekleşmiştir. Bu bulgulardan yola çıkılarak öğrencilerin ön bilgi ve fikirlerinin olduğu bilimsel tartışmalara katılmakta daha istekli oldukları söylenebilir. Bilimsel argümantasyon yönteminde ön bilgi düzeyi farklı öğrencilerin daha farklı bakış açılarına sahip oldukları, bilgi sahibi oldukları konularda farklı fikirler ürettikleri farklı araştırmalarda da saptanmıştır (Sağır ve Kılıç, 2013). Mevcut araştırma öğrencilerin ön bilgi düzeyi ile argümantasyon becerisi arasında bir bağdaşım kurmayı amaçlamamakla birlikte; ilgili araştırmaları destekler niteliktedir.

Geçmişten günümüze insanlığın bilimsel bilgi ile ilgili en genel geçer problemi, bilimselliğin ve sınırlarının ne olduğunun tam olarak algılanamamasıdır. Bu sebeple toplum, bilim adı altında ortaya atılan her türlü iddia ve bilginin peşinden kolaylıkla sürüklenebilmektedir. Ekonomik çıkarlar ve popülarite arzusu ile toplumu yönlendirmeye çalışan sözde-bilimin kurmaca dili onun iç yapısını anlamayanlara kolayca dayatılmakta ve her düzeyde eğitim görmüş insanlar, bu sözde yaklaşımlarla kolayca manipüle edilmektedir. Bu durum sözde-bilim tartışmasını gündeme getirmenin gerekliliğini ortaya koymaktadır. Insanlara her türlü kitle iletişim yoluyla aktarılan bu bilgi yığınlarının bilimselliği konusunda bilinçlendirme intiyacı ortaya çıkmaktadır. Günümüzde bireylerin bilimsel olan bilgiyi sözde-bilimsel bilgiden ayırt edebilecek ölçütlerin farkında olması ile mümkün olabileceği düşünülen bu bilinçlendirmenin, toplumu oluşturan bireylerin eğitimlerinin ilk dönemlerinden itibaren bilimsellik tartışmaları içerisinde yer alması ile gerçekleştirilebileceği öngörülmektedir.ilköğretim çağından başlayarak öğrencilere kazandırılacak bilimsel argümantasyon becerilerinin öğrencilerin bilim adı altında sunulan bilgileri eleştirel okumasında fayda sağlayacağı düşünülmektedir.

\section{Kaynakça}

Aarnio, K. ve Lindeman, M. (2005). Paranormal beliefs, education, and thinking styles. Personality and Individual Differences, 39(7), 1227-1236.

American Assocation for the Advancement of Science (1993). Benchmark for science literacy: A Project 2061 report. New York: Oxford University Press.Çekmez, E., Yıldız, C. ve Bütüner, S. Ö. (2012). Phenomenographic research method. Necatibey Eğitim Fakültesi Elektronik Fen ve Matematik Eğitimi Dergisi (EFMED), 6(2), 77-102.

Çetinkaya, E., Turgut, H., Duru, K. ve Ercan, S. (2015). Bilimsel okuryazarlıkta ilk adım: akademik bilgi düzeylerinin bilim, sözde-bilim ayrımı bağlamında geliştirilmesi: iridoloji örneği. Dicle Üniversitesi Ziya Gökalp Ĕ̈itim Fakültesi Dergisi, 24, 446-476.

Chalmers, A. F. (2013). What is this thing called science? Indianapolis: Hackett Publishing.

De Robertis, M. M. ve Delaney, P. A. (1999). A second survey of the atitudes of university students to astrology and astronomy. Journal of the Royal Astronomical Society of Canada, 94, 112.

Derry, G. N. (1999). What science is \& How it works. NJ: Princeton University Press.

Driver, R., Newton, P. ve Osborne, J. (2000). Establishing the norms of scientific argumentation in classrooms. Science education, 84(3), 287-312.

Duschl, R.A. ve Osborne, J. (2002). Supporting and promoting argumentation discourse in science education. Studies in Science Education, 38(1), 39-72.

Erduran, S. ve Jimenez Aleixandre, M. P. (2007). Argumentation in science education: Perspectives from classroom-based research. Dordrecht: Springer Science.

Eve, R. A. ve Harrold, F. B. (1986). Creationism, cult archaeology, and other pseudoscientific beliefs: a study of college students. Youth \& Society, 17(4), 396-321.

Feyerabend, P. (1989). Yönteme Hayır (Çev. Ahmet Inam). İstanbul: Ara Yayınclık. 
Gardner, M. (1957). Fads and fallacies in the name of science. New York: Dover Publications.

Gillies, D. (1998). Philosophy of science in the 20th century: Four central themes. Oxford: Blackwell Publishers. Goode, E. (2002). Education, scientific knowledge, and belief in the paranormal. Skeptical Inquirer, 26(1), 24-27.

Günel, M., Kıngır, S. ve Geban, Ö. (2012). Argümantasyon tabanlı bilim öğrenme yaklaşımının kullanıldığı sınıflarda argümantasyon ve soru yapılarının incelenmesi. Eğitim ve Bilim, 37(164), 316-330.

Güler, A., Halıcıoğlu, M. B. ve Taşğın, S. (2015). Sosyal bilimlerde nitel araştırma. Ankara: Seçkin Yayıncilık.

Impey, C., Buxner, S. ve Antonellis, J. (2012). Non-scientific beliefs among undergraduate students. Astronomy Education Review, 11(1), 101-111.

Kuhn, D. (1993). Science as argument: implications for teaching and learning scientific thinking. Science education, 77(3), 319-337.

Kuhn, T. S. (1962). The Structure of scientific revolutions. Chicago: University of Chicago Press.

Lakatos, I. (1991). Science and pseudo-science. M. Curd ve J.A. Cover, (Ed.). Philosophy of Science (s.22-23). New York: Norton.

Lindeman, M. ve Aarnio, K. (2007). Supersitious, magical, and paranormal beliefs: an integrative model. Journal of Research in Personality, 41, 731-744.

Losh, S. C. ve Nzekwe, B. (2011). Creatures in the classroom: preservice teacher beliefs about fantastic beasts, magic, extraterrestrials, evolution and creationism. Science \& Education, 20(5-6), 473-489.

Lundström, M. (2007). Students' beliefs in pseudoscience. European Science Education Research Association Conference (ESERA), Malmö: Sweden.

Lundström, M. (2011). Decision-making in health issues: teenagers' use of science and other discourses. Malmö: Malmö University Press.

Mahner, M. (2007). Demarcating science from non-science. General Philosophy of Science, Focal Issues.

Martin, M. (1994). Pseudoscience, the paranormal, and science education. Science and Education, 3, 357-371.

McLean, C. P. ve Miller, N. A. (2010). Changes in critical thinking skills following a course on science and pseudoscience: a quasi-experimental study. Teaching of Psychology, 37(2), 85-90.

Milli Eğitim Bakanlığı (MEB) (2013). Illköğretim kurumları fen bilimleri dersi öğretim programı. Ankara: Milli Ĕgitim Bakanlığı.

National Research Council (Ed.). (1996). National science education standards. National Academy Press.

Nickles, T. (2006). Problem of demarcation. S. Sarkar ve J. Pfeifer (Ed.). The philosophy of science an encyclopedia (pp. 188-197). New York: Routledge.

Osborne, J., Erduran, S. ve Simon, S. (2004). Enhancing the quality of argumentation in school science. Journal of Research in Science Teaching, 41(10), 994-1020.

Park, R. L. (2000). Voodoo Science: The Road from Foolishness to Fraud. Oxford: Oxford University Press.

Peoa, A. ve Paco, O. (2004) Attitudes and views of medical students toward science and pseudoscience. Medical Education Online, 9(4), 1-7.

Popper, K. R. (1934). Logik der Forshung. Viyana: Julius Springer Press.

Preece, P. F. ve Baxter, J. H. (2000). Scepticism and gullibility: The superstitious and pseudoscientific beliefs of secondary school students. International Journal of Science Education, 22, 1147-1156. 
Rice, T. W. (2003). Believe it or not: religious and other paranormal beliefs in the United States. Journal for the Scientific Study of Religion, 42(1), 95-106.

Sandoval, W. A. ve Millwood, K. A. (2008). What can argumentation tell us about epistomology? Dalam Erduran, S., ve Maria, PJ. (Ed.) Argumentation in Science Education: perspectives from classroom-based research (pp. 68-85): Springer.

Smith, M. U. ve Scharmann, L. C. (1999). Defining versus describing the nature of science: a pragmatic analysis for classroom teachers and science educators. Science Education, 83(4), 493509.

Sönmez, V. (2008). Bilim Felsefesi. Anı Yayıncılık, Ankara.

Sugarman, H., Impey, C., Buxner, S. ve Antonellis, J. (2011). Astrology beliefs among undergraduate students. Astronomy Education Review, 10(1), 10-21.

Hansson, S. O. (2008). Science and pseudo-science. Stanford Encyclopedia of Philosophy.

Thagard, P. R. (1978). Why astrology is a pseudoscience. In PSA: Proceedings of the Biennial Meeting of the Philosophy of Science Association (pp. 223-234). Philosophy of Science Association.

Toulmin, S. (1958). The uses of argument. Cambridge: Cambridge University Press.

Tümay, H. ve Köseoğlu, F. (2011). Kimya öğretmen adaylarının argümantasyon odaklı öğretim konusunda anlayışlarının geliştirilmesi. Türk Fen Eğitim Dergisi, 8(3), 105-119.

Turgut, H. (2009). The nature of science teaching in the context of demarcation issue. Paper presented at the 10. IHPST Bienal Conference, Indiana, USA.

Turgut, H. (2010). Fen ve teknoloji öğretmen adaylarının bilimsel, sözde-bilimsel ayrımına yönelik algıları. Eğitim ve Bilim, 34(154), 50-68.

Turgut, H., Akçay, H. ve İrez, S. (2010). Bilim sözde-bilim ayrımı tartışmasının öğretmen adaylarının bilimin doğası inanışlarına etkisi. Kuram ve Uygulamada Eğitim Bilimleri, 10(4), 2621-2663.

Tutar, H. (2014). Bilim ve sözde bilim. Ankara: Seçkin Yayıncılık.

Uluçınar-Sağır, Ş. U. ve Kılıç, Z. (2013). İlköğretim öğrencilerinin bilimin doğasını anlama düzeylerine bilimsel tartışma odaklı öğretimin etkisi. Hacettepe Üniversitesi Eğitim Fakültesi Dergisi, 44(44), 308-318.

Uslu, F. (2011). Bilimselliğin kriteri ve sınırları problemi-bilim, bilim olmayan ve sahte bilim. Hitit Üniversitesi ilahiyat Fakültesi Dergisi, 19(19), 5-35.

Üstünkaya, I. ve Savran Gencer, A. (2012). Illköğretim 6. sınıf seviyesinde bilimsel tartışma (argumentation) odaklı etkinliklerle dolaşım sistemi konusunun öğretiminin akademik başarıya etkisi. X. Ulusal Fen ve Matematik Eğitimi Kongresi.

Wynn, C. M. ve Wiggins, A. W. (2008). Yanlış yönde kuantum sıçramalar. (Çev.Aykut Kence). Ankara: Tubitak yayınları

Yıldırım, A. ve Şimşek, H. (2011). Sosyal bilimlerde nitel araştırma yöntemleri. Ankara: Seçkin Yayıncilık. 


\section{Extended Summary}

Science literacy is one of the main objectives for contemporary science curricula. Scientific literate individuals have sufficient knowledge about how to separate scientific knowledge from nonscientific knowledge. The problem of the separation of scientific knowledge from non-scientific knowledge, reserachers are called it as a "demarcation problem". Determining the boundaries of science is primarily concerned for science because it is necessery to define the epistemological structure and value of scientific knowledge as well as the characteristics of non-scientific information that distinguish scientific and non-scientific information.

In order for the students to be able to develop this awareness, it is necessary to provide a learning environment for students to make healthy decisions by evaluating the information, data as well as to question and think critically. Students should be able to think about alternative explanations with an open-minded, make conscious decisions by critically evaluating the arguments.

When educational studies in Turkey and in the world are examined, there is not much educational work for scientific pseudo-science differentiation. Therefore the aim this research is to develop science pseudo-science discrimination skills of seventh grade students through Argument Based Learning $(A B L)$ activities. The sub-problems arranged for this purpose are as follows:

1. What are the views of the seventh-grade students' awareness towards science pseudo-science seperation?

a) What are students' criteria for the scientific knowledge?

b) What are the sources of scientific knowledge?

c) What are students' criteria for the pseudo-scientific knowledge?

2. What is the impact of argumentation-based learning activities on students' awareness of science pseudo-science separation?

a) Has there been any significant improvement in the criteria of scientific knowledge between before and after the study?

b) Has there been any significant improvement in pseudo-scientific criteria between before and after the study?

This study used qualitative research method. The sample of the research consists of 24 seventh grade students. Student interviews, Toulmin Argument Model and Group Discussion Forms were used as data collection tools in the research. The data were analyzed by content analysis method.

As a result of the study, it was found that using argumentation as a teaching model help students to increase their understanding of how to seperate scientific knowledge from and pseudo-scientific information. At the end of the study, students used mainly "universality", "authority view", "scientific method", "testability" criteria for scientific knowledge. Also, students have more accurate classification of pseudo-scientific field and news. When the students were asked about the sources of scientific knowledge, different opinions were determined between pre-and post interview data. It is seen that students use more descriptive, broad, comprehensive, clear and developed expressions instead of shallow expressions they established at the beginning of the process.

In the future, argumentation skills should be developed starting from kindergraden through all grades to have scientifically literate citizens. 